удК 342(477)

DOI https://doi.org/10.32837/apdp.v0i83.123

П. В. Куфтирєв

\title{
ЮРИДИЧНИЙ ЗМІСТ ПОНЯТТЯ ЕЛЕКТРОННОЇ ДЕМОКРАТІЇ
}

Постановка проблеми. Визначення юридичного змісту будь-яких понять має неабияке значення в юриспруденції, оскільки дозволяє вести мову не просто про академічну чистоту термінології, але й правильно юридично тлумачити категорії, а відтак вірно застосовувати норми права. Аналіз поняття «електронна демократія» дозволяє більш точно визначити місце цього юридичного феномену у структурі правовідносин, що дає змогу законодавцю врегулювати такі суспільні відносини у найбільш оптимальний спосіб правового регулювання.

Аналіз останніх досліджень і публікацій. Питаннями електронної демократії та інформаційного суспільства займалися такі вчені М. Порат, Т. Стоун'єр, Р. Карц, М. Кастелльс, Дж. Несбі, С. Нор, А. Мінк, С. Постер, У. Дж. Мартін, Л. Карвалікс та інші.

Виділення не вирішених раніше частин загальної проблеми. В українській юриспруденції до цього часу відсутнє єдине комплексне дослідження поняття електронної демократії, а наявні наукові дослідження переважно вибірково досліджують лише окремі сторони цього явища.

Формулювання мети статті. Автор не ставив за мету навести простим переліком якомога більшу кількість визначень електронної демократії. Його метою було навести найбільш визначні, цікаві, спірні, етапні визначення та проаналізувати їх, виявити слабкі та сильні сторони

Виклад основного матеріалу дослідження. За даними Британської енциклопедії («Британіки») у статті Ендрю Чедвіка, присвяченій визначенню «е-демократії», цей термін ймовірно походить від назви відомого у США незалежного інтеренет-форуму «Міннесота Е-Демократія» (Minnesota E-Democracy), який було засновано у 1994 році, який згодом фундатори перетворили у сайт «Е-Democracy. org», який існує і досі та позиціонує себе як піонерський проект у сфері е-демократії. Хоча такі дані є досить умовними і точного авторства цієї дефініції не встановлено, правоволодільця чи легітимовано визнаного автора допоки не виявлено, що дає підстави вважати цей термін «народним».

Енциклопедія «Британіка» запозичує для визначення «е-демократії» відповідну статтю Ендрю Чедвіка з «Енциклопедії урядування» (Encyclopedia of Governance, 2007) [1] і подає наступне визначення - це використання інформаційних та комунікаційних технологій зміцнення демократії, що у деяких випадках здатна замінити представницьку демократію.

Автор, професор політичних наук Університету Лондона використав праксеологічний (діяльнісний підхід), тобто «е-демократія - ие використання» (певна дія суб’єкта); і при цьому досить радикально окреслив її роль, як інструментарію, здатного замінити представницьку демократію. Цей підхід є досить поширеним у роботах, присвячених е-демократії, і сутність його зводиться до того, що е-демо-

(ㄱ) П. В. Куфтирєв, 2019 
кратія утворює собою нову якісну сутність демократії, що трансформує представницькі інститути шляхом використання технологій (переважно інформаційнокомунікаційних - IКT).

3 таких же позицій пояснює зміст е-демократії і один з найвідоміших світових фахівців з е-демократії, який вважається одним із піонерів цього напряму Стівен Кліфт. На його думку, е-демократія означає використання інформаційних і комунікаційних технологій і стратегій демократичними діячами (урядами, обраними посадовцями, медіа, політичним організаціями, громадянами/виборцями) всередині політичних і управлінських процесів місцевих спільнот, націй та на міжнародному рівні [3].

Аналогічно визначає е-демократію дослідник В.І. Дрожжинов, який вважає що під е-демократією варто розуміти застосування IКТ в інтересах удосконалення та укріплення демократичних інститутів у сучасному суспільстві, підвищення участі громадян у політичному процесі [4].

Існує підхід, який намагається виділити вузьке та широке розуміння е-демократії. У вузькому розумінні е-демократію розглядають як використання електронної підтримки для забезпечення відповідних конституційних прав, що вимагають тих чи інших формальних рішень; у широкому - врахування думки і залучення громадян і організацій у політичні відносини і процеси [5]. В цьому варіанті застосований вже вищеназваний традиційний для політології підхід розуміння е-демократії, як того чи іншого виду діяльності.

Праксеологічний підхід у визначенні е-демократії не позбавлений сенсу, оскільки з точки зору сутнісного сприйняття цієї категорії одразу окреслює рамки іï змісту і визначає її роль у суспільних відносинах. Але з юридичної точки зору навряд чи задовольнить будь-якого правознавця, оскільки не дозволить унормувати визначення е-демократії, як конституційно-правового явища, як відповідного державно-політичного режиму, розбалансує загальноюридичний контекст правосприйняття i, як наслідок, не дозволить законотворцю виробити юридичні критеpiї е-демократії з метою подальшого врегулювання таких правовідносин направляючи їх на юридичну охорону та захист прав і свобод людини. Тому законотворчі інституції держави змушені будуть шукати інші правові критерії для визначення е-демократії, як нормативної категорії.

3 інших позицій дається погляд на е-демократію у досить відомому колективному міжуніверситетському дослідженні 2003 року «Оиінка використання нових технологій з метою сприяння делократї̈ у Європі. Е-делократизація парламенmів ma napmiǔ y Європі» (А. Трехсель, Р. Кіс, Ф. Мендес, Ф.С. Шміттер, та інші): е-демократія складається з усіх електронних засобів комунікацій, що дозволяють/ уможливлюють для громадян застосування зусиль для тримання керівників/політиків відповідальними за свої дії у сфері публічного життя.

Залежно від аспектів демократії, що просуваються, е-демократія може використовувати різні технології для: 1) підвищення транспарентності політичного процесу; 2) посилення прямого залучення і участі громадян; 3) удосконалення якості формування думок шляхом відкриття нового простору для інформації і обговорення [6]. На думку цього колективу авторів, техніками е-демократії є е-до- 
ступ, е-консультації, е-петиції, е-голосування, е-форуми. Відтак, таке технологізоване визначення ставить знак рівності між е-демократією та сукупністю ІКТ, що не зовсім правильно, адже відбувається підміна понять між результатом та засобом його досягнення. Засоби комунікації - це способи забезпечення демократії, але не самоціль демократичного режиму. Важко вести мову про побудову е-демократії в цілому у недемократичній країні.

Найпоширеніша мережева енциклопедія інтернету Вікіпедія станом на березень 2016 року в англомовній версії використовує визначення е-демократії, що надане колективом авторів-дослідників (Хусейном Джафаркарімі, Алексом Сім, Робабом Саадатдуст, Джи Мей Xi), щоправда представниками технічних наук, з їх колективної статті «Вплив IКТ на посилення ролі громадян у прийнятті владних рішень» [7]. 3 точки зору цих авторів, е-демократія - це явище 21 сторіччя, що включає у себе інформаційні та комунікаційні технології просування демократії, тобто форма правління, за якої всі дорослі громадяни набувають рівних прав пропонувати, розробляти та створювати законодавство [8]. Автори зазначеної статті у своїх розмірковуваннях посилаються на доробки Ендрю Чедвіка.

Незважаючи не певну суперечливість, перебільшену технологізованість та правову неточність такого підходу, цінність його полягає у тому, що воно відносить е-демократію до явищ правового порядку, хоча і зводить його тільки до законотворчої ініціативи прямої демократії. Втім, автори і не ставили перед собою мети надавати правове визначення, але зрештою це одне з небагатьох визначень, що актуалізує правовий погляд на електронну демократію та юридизує це поняття, хоча і не зовсім точно з точки зору розмежування форми правління та форми політичного режиму.

Разом із тим україномовний (як і російськомовний) варіант Вікіпедії надає дещо інше бачення поняття е-демократії і визначає останню як форму демократії, що характеризується використанням інформаційно-комунікаційних технологій (IКТ) як основного засобу для колективних розумових (краудсорсинг) і адміністративних процесів (інформування, прийняття спільних рішень (електронне голосування, контролювання виконання рішень) на всіх рівнях, починаючи з рівня місцевого самоврядування і закінчуючи міжнародним [9].

Е-демократію намагаються визначити, як форму демократії і зазначають про це, як про усталену категорію, вводячи у експерно-науковий лексикон нову форму демократії. При цьому всі зазначені електронні ресурси у якості синоніма е-демократії використовують поняття цифрової демократії (або як калька з англійської мови діджитальна), відео-демократії, інтернет-демократії, інформаційної демократії, віртуальної демократії, мережевої демократії, вікі-демократії, аватарної демократії, крауд-демократії, кібердемократії, соціокібернетичної демократії, он-лайн демократії тощо. Існує підхід у тлумаченні е-демократії, як «хмарної демократії» [10].

M.C. Вершинін запропонував бачення е-демократії, як нової комп'ютерно-опосередкованої форми політичної комунікації і вважає, що у теорії демократії відбулися зсуви під впливом мережі Інтернет [11]. Підхід М.С. Вершиніна є домінуючим для наукової політології пост-радянських країн. Проте, слід звернути особливої уваги на ту обставину, що поняття «політична система», до якої звернув- 
ся М.С. Вершинін, є американським політико-правовим аналогом європейського наукового поняття політичний (державно-політичний) режил.

Через ключове поняття - «форма політичної комунікації» - е-демократію визначає і М.Н. Грачев, який вважає, що остання є заснованим на застосуванні мережевих комп'ютерних технологій механізмом політичної комунікації, що сприяє реалізації принципів народовладдя і дозволяє привести політичний устрій у відповідність до реальних потреб інформаційного суспільства, що встановлюється [12]. В цьому випадку автор пропонує опосередкувати цю категорію через поняття «механізм».

В.В. Трофімов вважає, що е-демократія - це вираз у мережі Інтернет, волевиявлення з приводу ініціації проекту нормативного рішення або збору голосів у підтримку прийняття певного правового акту чи голосів протесту проти будь-яких правотворчих ініціатив, а також прийнятих юридичних рішень. Одразу слід зазначити, що автор надав таке визначення е-демократії з певною часткою умовності [13]. Проте, у цьому випадку мова йдеться не про е-демократію, як форму загального поняття демократії, а скоріше про форми самої е-демократії. Важко погодитись із думкою автора стосовно того, що недостатній ефект від правотворчої ініціативи у безпосередній площині правового життя може бути частково компенсований активністю громадян у віртуальному просторі за допомогою форм так званої електронної демократії. Щоправда, ця думка автором була висловлена у якості гіпотези.

Електрона демократія не є компенсацією нестачі будь-якої з форм демократії, a є самостійною інтегрованою формою демократії, яка зародилася саме у тих країнах, де важко говорити про нестачу демократії чи низьку політичну активність громадян. В той же час автору видається слушною і правильною думка В.В. Трофімова стосовно того, що електрона демократія сприяє формуванню актуального права - права, що відповідає повсякденним потребам людей та такого, що виражає ïх необхідні запити та юридично значимі соціальні інтереси.

Вдалим саме з юридичної точки зору є визначення «мережевої демократії», надане С.В. Всильєвою, яка свою думку сформулювала наступним чином: «Мережева демократія означає здійснення громадянами влади та їх участь в управління справами держави за допомогою електронних мереж загального користування. У цьому їі головна відмінність від інших типів демократії» [14]. Таким чином, автор спрямовує своє визначення е-демократії (мережевої демократії) через формулу «реалізації права», оскільки здійснення права - це процес реалізації правових можливостей, які надаються законом (чи договором) носію суб'єктивного права (правоволодільцю, суб’єкту). Підхід є досить слушним і юридично зваженим, оскільки дозволяє корелювати е-демократію у правовідносинах, чітко ідентифікуючи її місце серед правових явищ. Проте, він розкриває лише одну з граней е-демократії - лише як суб'єктивне право.

Досить технологізоване визначення е-демократії пропонують надати Енді Брек та Філ Нобл, які зводять її до «використання інтернету урядом, політичними партіями і правозахисними групами для постачання інформації, комунікацій, надання послуг чи підтримки участі для розвитку більш міцних дебатів серед громадян» [15]. Ці західні експерти не надто переймаються чистотою поняття та його змістом, 
хоча сама робота «Е-демократія навколо світу», де міститься таке їх визначення, $\epsilon$ досить цікавою і новаторською.

Існує підхід до визначення е-демократії, як форми тільки прямої демократії, що характеризується використанням IКТ, як основного засобу для колективних розумових та адміністративних процесів (інформування, прийняття спільних рішень, електронне голосування, контролювання виконання рішень ) на усіх рівнях, починаючи з рівня місцевого самоврядування і закінчуючи міжнародним рівнем [16]. Цей підхід вже $є$ не настільки радикальним, щоб оголошувати нову форму демократії і спонукати дослідників вишукувати витоки і особливості е-демократії у прямій демократії, як одній із форм демократії, як виду державно-політичного режиму.

Існують діаметрально протилежні підходи, які визначають е-демократію способом удосконалення тільки представницької демократії. Так, Енн Макінтош (Ann Macintosh) вважає, що е-democracy - це використання IКТ для підтримки демократичних процесів прийняття політичних рішень, більш широкого залучення (participation) у ці процеси громадян та укріплення репрезентативної демократії [17]. Ця професор убачала розвиток е-демократії в рамках традиційної і домінуючої форми представницької демократії, але при цьому спиралася на концепцію електронної участі (E-Participation), на якій автор зупиниться нижче.

Через функціональність визначає електрону демократію Н.О. Обривкова, ідентифікуючи її як відкритість влади суспільству, що обумовлює оптимізацію державного управління шляхом активного залучення до неї пересічних громадян [18]. У цьому випадку дослідник детермінує пряму демократію е-урядом, оскільки робить посилання на оптимізацію державного управління. Слідуючи цій логіці, е-демократія забезпечується поліпшенням е-уряду, що є дисонансом між цими двома поняттями, хоча позитивним є посилання на необхідність залучення громадян. Транспарентність (прозорість, гласність, відкритість) у діях владних інституцій $є$ однією з найважливіших ознак демократії, але не єдиною, тому зводити е-демократію виключно до відкритості не варто.

Досить популярною і відомою на пост-радянському соціальному просторі є робота Ф. Крашеніннікова та Л. Волкова «Хмарна демократія» («Облачная демократия»), яка розповсюджується завдяки вільному електронному доступу в інтернеті до цього дослідження. Автори розвивають своє бачення розвитку демократії у контексті паралельному, але досить близькому до е-демократії.

Сутність концепції хмарної демократії в принципі подібна до так званих хмарних сервісів в інтернеті [19]. Цей підхід ще відомий під іншими назвами: «плинуча (або "рідка») демократія» (liquid democracy), або «демократія делегування» (delegative democracy). Останню концепцію активно розробляв Брайан Форд [20]. Ії̈ зміст полягає у тому, що громадянин завдяки технологіям може делегувати свій голос експертам у певних сферах, які викликають у нього довіру, або навіть поділити свій голос поміж декількома делегатами, а частину залишити собі. Хмарну демократію у розумінні зазначених авторів можливо досягнути лише завдяки електронним технологіям.

Своє бачення е-демократії Ф. Крашенінніков та Л. Волков висловили у наступній своїй роботі «Пересічна електронна демократія», де визначили останню, як 
можливість будь-якого громадянина, незалежно від його місця знаходження, брати участь у політичному процесі, у розробці та прийнятті управлінських рішень, i є одним із головних досягнень сучасності у сфері політичного управління. На їх думку, саме е-демократія окреслює горизонти подальшого розширення прямої демократії у суспільстві [21]. 3 юридичної точки зору такий підхід надає погляд на е-демократію, як на суб'єктивне право - «можливість громадянина ... брати участь» .

Якщо виходити з класичного юридичного підходу до поняття демократії, як виду політичного режиму, то таке визначення, поряд з усіма його позитивними ознаками позбавляє демократію рис об'єктивної категорії, зводячи його лише до характеристики суб'єктивної правомочності громадянина. У цьому сенсі тоді немає можливості вести мову про е-демократію, як форму демократії, а лише тільки як про суб'єктивне право, хоча позиція авторів стосовно співвідношення е-демократії та прямої демократії заслуговує на увагу. Автори слушно вважають, що ефективно функціонуюча система демократії, яка залучає у себе сотні, тисячі чи мільйони людей, здатна досить швидко підкреслити та зробити неминучим остаточне банкрутство традиційних, застарілих методів прийняття політично значимих рішень [22].

Таким чином, Ф. Крашенінніков та Л. Волков досить помірковано підходять до поширеної позиції про те, що е-демократія є новою формою демократії, про що досить рішуче заявляє ціла низка авторів. Позиція цієї групи досить розрізнених і не пов'язаних між собою експертів полягає у тому, що ІКТ дозволяють утворити нову форму демократії, яка не була раніше відома політ-правовим вченням, історії політології, соціології, теорії права, історії конституціоналізму; а е-демократія володіє досить специфічними рисами, що дозволяють ї̈ відмежовувати від відомих форм демократії.

Висновки. Існує широка палітра концептуальних підходів до визначення прямої електронної демократії. Аналіз основних концептів дозволяє більш точно виявляти юридичний складник цього політико-правового явища і на цьому грунті будувати моделі законодавчого врегулювання правовідносин електронного доступу до реалізації конституційних прав.

\section{Jimepamypa}

1. Britanica. Electronic version. Електронний ресурс. Режим доступу: http://www.britannica.com/ topic/e-democracy.

2. E-encyclopedia of Governance. SAGE Publications, London, 2006-2007, 1232 pages.

3. Clift S. E-democracy, E-governance \& public network / S. von Clift // Open Source Jahrbuch 2004, Berlin: Lehmanns Media, 2004, Pp. 317-331.

4. Дрожжинов В.И. Электронное правительство // Совершенствование государственного управления на основе его реорганизации и информатизации. Мировой опыт / Под ред. В.И. Дрожжинова. M., 2002, C. 11-88.

5. Голычев А.А. Электронная демократия как фактор повышения политического участия граждан современной России. Дисс. канд. полит. наук. М., 2006, 238 с.

6. Evaluation of the Use of New Technologies in Order to Facilitate Democracy in Europe. E-democratizining the Parliaments and Parties of Europe, Geneva \& Florence, October 2003, p. 10. Електроний ресурс. Режим доступу: http://www2.media.uoa.gr/people/tsaliki/wp-content/uploads/2010/07/ Report_eDemocracy_in_Europe_2004.pdf.

7. International Journal of Emerging Technology and Advanced Engineering Website. Електроний ресурс. Режим доступу: www.ijetae.com(ISSN 2250-2459, ISO 9001:2008 Certified Journal, 
Volume 4, Issue 1, January 2014). Електроний ресурс. Режим доступу - http://www.ijetae.com/files/ Volume4Issue1/IJETAE_0114_109.pdf.

8. Вікіпедія. Електронна енциклопедія. Електроний ресурс. Режим доступу: Вікіпедія. Електронна енциклопедія. Електроний ресурс. Режим доступу: https://en.wikipedia.org/wiki/E-democracy.

9. Вікіпедія. Електронна енциклопедія. Електроний ресурс. Режим доступу: https://uk.wikipedia. org/wiki/Електрона_демократія.

10. Леонид Волков, Фёдор Крашенинников. Облачная демократия. 2011 г Екатеринбург, октябрь 2010 - май 2011 года. Електроний ресурс. Режим доступу: http://cdem.ru/.

11. Вершинин М.С. Электронная демократия как компьютеро-опосредованная форма политической коммуникации // Материалы международной научно-практической конференции «Коммуникация: теория и практика в различных социальных контекстах. Коммуникация-2002» («Communication Across Differences»), Ч. 1. Пятигорск : Изд-во ПГЛУ, 2002, с. 153-155.

12. Грачев М.Н. Политическая коммуникация: теоретические концепции, модели, векторы развития : Монография, М., Прометей, 2004, 328 с.

13. Трофимов В.В. Формы электронной демократии и процесс формирования права в современной России. Гл. 34 в Кн.: Государство. Конституция. Родина: к поискам национальной идеи и новой доктрины государства. Москва : Проспект, 2015, 317 с.

14. Васильева С.В. Типология демократии: к вопросу о реальном наполнении системы осуществления гражданами власти и их участия в управлении делами государства. Електронний документ. Режим доступу: www.hse.ru/data/2010/03/29/.../Васильева\% 20РПА\% 20сокр..doc.

15. Andy Brack, Phil Noble, E-Democracy around the World: A Survey for the Bertelsmann Foundation, Summer 2001 p. 1. Електроний ресурс. Режим доступу: http://web.umoncton.ca/umcmsitesgr/cybergouvernement/Noble.pdf.

16. Кононцева И.Е. Электронная демократия. Электронное пособие. КУ «Севастопольский центр переподготовки и повышения квалификации работников органов государственной власти, органов местного самоуправления, государственных предприятий, учреждений и организаций». Протокол № 6 від 29.11.2012 року. Севастополь, 2012 p.

17. Macintosh A. "Characterizing E-Participation in Policy-Making», In the Proceedings of the ThirtySeventh Annual Hawaii International Conference on System Sciences (HICSS-37), January 5 - 8 2004, Big Island, Hawaii.

18. Обрывкова Н.О. Электронная демократия в современном постиндустриальном обществе. Автореферат дис. ... канд. полит. наук. СПб., 2006, 22 с.

19. Великанов К. О демократии обыкновенной, прямой и электронной // Отчественные записки Выпуск журнала № 6 (57), 2013.

20.Брайан Форд. Жидкая демократия. Електроний ресурс. Режим доступу: http://www.brynosaurus.com/deleg/deleg.pdf.

21. Волков Л., Крашенинников Ф. Посредственная электронная демократия. 13.02.2012, Электронный ресурс, Режим доступа: http://www.vedomosti.ru/opinion/news/1501361/posredstvennaya demokratiya.

22. Волков Л., Крашенниников Ф. Облачная демократия. - Екатеринбург, 2011. 64 с. Електроний peсурс. Режим доступу: http://fyodor.su/.

\section{Анотація}

Куфтирєв П. В. Юридичний зміст поняття електронної демократії. - Стаття.

У статті проаналізовано підходи до визначення поняття «електронна демократія». Автором було досліджено вітчизняні та зарубіжні електронні ресурси та академічні джерела, в яких надаються визначення цієї дефініції. Встановлено, що генеза назви «е-демократія» походить від ранніх інтернет-форумів 90 -х років XX ст. Порівняно визначення, які надані в україномовній та англомовній версіях вільній інтернет-енциклопедії «Вікіпедія», а також у інших відомих довідкових ресурсах (зокрема, в енциклопедії «Британіка»).

Автор зробив висновок, що політико-правова категорія електронної демократії містить як політико-соціологічні, так і юридичні аспекти. Автор звернув увагу на переваги так званого праксеологічного підходу, тобто визначення прямої електронної демократії у динаміці її розвитку. Було звернуто увагу на те, що існує два підходи до розуміння е-демократії: як нової окремої форми демократії, що існує поряд із представницькою та прямою, тобто, фактично є третьою формою демократії; а також е-демократія розглядається лише як електронна версія існуючих традиційних форм демократії (прямої та 
репрезентативної). Автор розділяє другу позицію і вважає, що використання нових інформаційно-комунікаційних технологій не створює нового виду демократії, оскільки їі сутність, як виду політико-правового режиму не змінюється, а міняється лише носій, через який реалізується волевиявлення народу. Хоча при цьому свого характерного прояву е-демократія набуває саме у формі прямої (безпосередньої), оскільки у репрезентативній формі демократії відсутня така необхідність опосередковувати волевиявлення суб'єкта прийняття рішень за допомогою інформаційно-комунікаційних технологій.

Автором досліджено вузьке та широке розуміння е-демократії. У вузькому розумінні е-демократію розглядають як використання електронної підтримки для забезпечення відповідних конституційних прав, що вимагають тих чи інших формальних рішень; у широкому - врахування думки і залучення громадян і організацій у політичні відносини і процеси. Також проведено порівняння визначень е-демократія із тотожними дефініціями, які зустрічаються у науковій літературі - мережева демократія, кібер-демократія, теле-демократія тощо.

За результатами дослідження автор дійшов висновку, що вивчення витоків формування поняття е-демократії дозволяє більш глибоко опанувати різні сторони цього явища, яке містить у собі невичерпний потенціал свого прояву.

Ключові слова: електронна демократія, політико-правовий режим, конституційні системи.

\section{Summary}

Kuftyrev P. V. Legal content of the electronic democracy's concept. - Article.

In the article the approaches to defining the electronic democracy's concept are analyzed. The author has explored national and foreign electronic resources and academic sources in which definitions of this concept are given. It was established by the author that the genesis of the term "e-democracy" comes from the earlier internet fora of the 90 -s of the XX century. The definitions given in the English and Ukrainian languages Wikipedia, as well as in the known information resources (e.g. Encyclopedia Britannica), were compared.

The author came to conclusion that political-legal category of democracy contains both political-sociological and legal aspects. The author has paid attention to the advantages of the so called praxeological approach, i.e. research of the direct electronic democracy in the dynamics of its development. It was also drawn attention to the fact that there are two approaches to the understanding of the e-democracy: as a new separate kind of democracy, which exists alongside representative democracy, and alongside direct democracy, i.e. direct electronic democracy is, in fact, a third kind of democracy. E-democracy is also considered as an electronic version of the existing traditional forms of democracy (direct and representative).

The author shares the second approach and argues that the use of the new information-communication technologies does not create a new type of democracy because its essence as a kind of political-legal regime does not change; instead changes only the subject through whom the will of the people is being realized. At the same time, its characteristic feature e-democracy acquires in the form of direct democracy, because the representative form of democracy lacks the necessity to directly express the of will of the subject of decision taking by means of information-communication technologies.

The author has researched the narrow and broad understanding of e-democracy. In the narrow sense e-democracy is viewed as an employment of the electronic support to secure the corresponding constitutional rights that require certain formal decisions; in the broad sense - taking into account opinion of citizens and organizations and their involvement in political relations and processes.

The comparative analysis of the e-democracy definitions was performed with synonyms which can be encountered in the scientific literature, such as network democracy, cyber-democracy, tele-democracy, etc.

As a result of the research the author came to conclusion that exploration of the origins of the formation of the e-democracy definition allows to more deeply comprehend different aspects of this phenomenon, which contains unlimited potential of its manifestations.

Key words: electronic democracy, political and legal regime, constitutional systems. 